\title{
THE EXISTENCE OF THE STATE'S ROLE IN PROVIDING PRODEO LEGAL AID TO CITIZENS WHO ARE NOT ABLE BASED LAW NUMBER 16 OF 2011
}

\author{
Helmy Yahya Ramha Aji \\ Faculty of Social and Political Sciences, Universitas Diponegoro, Indonesia \\ Raden Muhammad Arvy Ilyasa \\ Faculty of Law, Universitas Negeri, Indonesia \\ Email: rmuhamadarvy123@gmail.com
}

Indonesia as a state of the law has guaranteed the constitutional rights of each of its citizens without exception as a form of protection of human rights contained in Article 1 paragraph (3) of the 1945 Constitution. Providing legal assistance to citizens who are unable as constitutional rights of every citizen and the State is obliged to protect the constitutional rights regarding obtaining guarantees, protections, and certainty of law that is fair and equal treatment before the law. Legal aid legally in Law Number 16 of 2011 is a legal service free of charge to legal aid recipients. The thing that becomes the basis for the provision of legal assistance by the State is because the State is responsible for providing legal assistance to disadvantaged citizens as a form of access to justice and equality before the law. The state has a role in terms of establishing regulations as the legal basis for implementing legal assistance for disadvantaged citizens. But in reality, in the development of legal aid, there are several problems between legal aid providers (advocates) and the State as a guarantor of the constitutional right to the realization of justice and equality before the law for every Indonesian citizen, including the poor.

Keywords: State of Law; Legal Aid; Constitutional Rights; Provider of Legal Assistance

The Indonesian Journal of International Clinical Legal Education ISSN 2721-8368

DOI: 10.15294/ijicle.v2i2.37843

(C) 2020 Authors. This work is licensed under a Creative Commons Attribution-ShareAlike 4.o International License. All writings published in this journal are personal views of the authors and do not represent the views of this journal and the author's affiliated institutions.

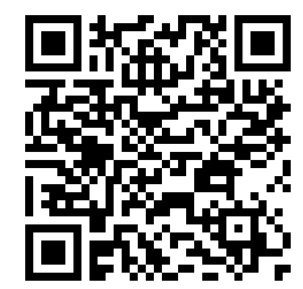


Aji \& Ilyasa

\section{INTRODUCTION}

Indonesia as a state of law recognizes and protects the rights of every individual without differing backgrounds for the realization of equality before the law based on Article 1 paragraph (3) of the 1945 Constitution. The right to legal assistance as part of human rights. Legal aid develops not only in the context of the defense of victims, but in the context of the defense of victims of violations of civil and political rights, and is one of the methods in the promotion and defense of rights in the economic, social and cultural fields. ${ }^{1}$ Guarantees for legal assistance are stipulated in Law Number 39 concerning Human Rights in Articles 17, 18, 19 and $34 .^{2}$ Indonesia has also ratified the International Covenant on Civil and Political Rights to realize guarantees of equality before the law without any discrimination related to race, color, nationality, religion and another status. Regarding the right to obtain legal assistance as a fundamental or fundamental right for someone affected by legal problems. Obtaining legal assistance as a form of access to justice for those who are dealing with the law.

Equality before the law is contained in Article 28D paragraph (1) of the 1945 Constitution, namely that every person has the right to recognition, guarantees of protection and fair legal certainty as a form of the consequences of the State as a rule of law. ${ }^{3}$ Legal aid as a service to give advice. The definition of legal assistance in the Criminal Procedure Code according to M. Yahya Harahap is covering the provision of legal aid services professionally and formally in the form of providing legal aid services for everyone involved in criminal cases, both for Free to disadvantaged communities and for those who are unable able by advocates by receiving rewards for services rendered. ${ }^{4}$

The role of the State in providing legal assistance in the form of the formation of regulations as a basis for implementing legal assistance in Indonesia. The State's method of providing legal assistance is by providing funds to legal aid providers. But in its development related to providing legal assistance to the poor in Indonesia, there are several problems, therefore the role of the state and legal aid providers is needed to be able to work together because the burden of providing legal aid

1 Adnan Buyung Nasution, Bantuan Hukum di Indonesia, Jakarta, LP3ES, pp. xi-xii; Adanan Buyung Nasution, Bantuan Hukum dan Hak Asasi Manusia, Bandung, Mandar Maju, pp. 13-15.

2 Law Number 39 of 1999 concerning Human Rights (Human Rights Act)

3 Afsinawati \& M.A Santosa, Bantuan Hukum Akses Masyarakat Marjinal Terhadap Keadilan: Tinjauan Sejarah, Konsep, Kebijakan, Peneraoan, dan Perbandingan di Berbagai Negara, Jakarta, LBH Jakarta, pp. 97-98. See also Ridwan Arifin, "Legal Services and Advocacy in the Industrial Revolution 4.0: Challenges and Problems in Indonesia". Indonesian Journal of Advocacy and Legal Services 1(2), 2020, pp. 159-162.

4 Yahya Harahap, Pembahasan Permasalahan dan Penerapaan KUHAP Penyidikan dan Penuntutan, Jakarta, SInar Grafika, p. 348. 
cannot be borne by advocates alone. So that the role of the state is needed constitutionally to be able to realize the guarantee of the constitutional rights of all Indonesian citizens, including the poor. This paper will discuss how the presence of the State's role in providing legal aid to the poor, as well as the definition of legal aid itself and its various regulations in the legal system in Indonesia.

Therefore, this paper analyzes two main point concerning, first, how is the existence of the role of the State in providing legal assistance in Indonesia, and second, hat is the arrangement and synergy of legal aid providers with the State in providing legal assistance in Indonesia?

The research method used in this study is a normative legal method that focuses on the formulation of problems and hypotheses through sampling, measuring variables, making analytic designs, and collecting data that ends at a conclusion. Then the approach used in this study is legal were by examining laws and regulations relating to legal issues regarding the role of the State in providing legal assistance and using approaches with descriptive qualitative research methods and indepth data analysis. There are two sources and types of data used in this study, namely primary and secondary data sources. The primary data sources obtained come from laws and regulations and other relevant legal regulations. While secondary data is obtained from references such as books, journals, literature reviews, documentation, publications, existing research studies, and sources from the internet. About the research subject in detail.

\section{THE EXISTENCE OF THE STATE'S ROLE IN PROVIDING LEGAL AID TO CITIZENS}

Indonesia as a state of law that upholds the presence of human rights contained in Article 1 paragraph (3) of the 1945 Constitution namely "The State of Indonesia is the State of Law". In the rule of law, the State

5 The 1945 Constitution of Republic of Indonesia. See also Ridwan Arifin, Rasdi, and Riska Alkadri. "Tinjauan Atas Permasalahan Penegakan Hukum dan Pemenuhan Hak dalam Konteks Universalime dan Relativisme Hak Asasi Manusia di Indonesia.” Legality: Jurnal Ilmiah Hukum 26(1), 2018, pp. 17-39; Nur Moh Kasim, and Sri Nanang Meiske Kamba. "Implementation of Assistance for Victims of Domestic Violence." Indonesian Journal of Advocacy and Legal Services 1(1), 2019, pp. 139-152. In almost the same context, legal assistance is needed especially in certain cases, for example cases relating to women and children both domestic violence. See Ayu Setyaningrum, \& Ridwan Arifin, “Analisis Upaya Perlindungan dan Pemulihan Terhadap Korban Kekerasan dalam Rumah Tangga (KDRT) Khususnya Anak-Anak dan Perempuan.” Jurnal Ilmiah Muqoddimah: Jurnal Ilmu Sosial, Politik dan Hummaniora 3(1), 2019, pp. 9-19; Firqotun Naziah, "Analisis Perlindungan Hukum Terhadap Wanita Korban Pemerkosaan". Lex Scientia Law Review 1(1), 2017, pp. 105-112; Kania Dewi Andhika Putri, and Ridwan Arifin. "Tinjauan Teoritis Keadilan dan Kepastian dalam Hukum di Indonesia (The 


\section{Aji \& Ilyasa}

recognizes and protects the rights of every individual without differentiating the background for the realization of equal treatment before the law (equality before the law). Equality before the law for all people must be balanced with equal treatment for all people. This dynamic understanding is believed to be able to provide a guarantee for access to justice for all people regardless of their background. According to Aristotle, justice must be shared by the State to all people and the law which has to protect it so that justice includes all people without exception.

Moh. Yamin defined the rule of law as "Power exercised by the government is based solely on the law and is not based on weapons, arbitrary power, or the belief that it is the power of the body that can decide all disputes within the State". Demands for greater protection have created a constitution that aims to protect the interests of individuals limiting the power of a State. All people must be considered equal before the law and all people must be able to appoint legal counsel (access to legal counsel) to defend their interests. ${ }^{6}$

The concept of the rule of law that adheres to the understanding of the rule of law, according to Dicey contains three elements:

1. Human rights are guaranteed through law

2. Equality before the law (equality before the law)

3. The supremacy of the rule of law and no arbitrariness without clear rules

Meanwhile, according to Immanuel Kant and Julius Stahl, the rule of law contains four types of elements, namely:

1. Recognition of human rights

2. There is a separation of powers to guarantee these rights

3. Government based on regulations (wetmatigheid van bestuur)

4. The existence of a state administrative court (Gultom, 2008: 11). In the rule of law relating to the protection of human rights contained in the State constitution. One of them is regulated in Article 27 paragraph (1) which explains that "all citizens are at the same position in law and the government is obliged to uphold the law and government with nothing except". Guarantees to obtain legal assistance are stipulated in Law No.39 concerning Human Rights in Articles 17, 18, 19 and 34. The Indonesian State has also ratified the International Covenant on civil and political rights as stipulated in article 16 and article 26 .

The Convention guarantees equality before the law, which means that everyone has the right to protection without discrimination against

Theoretical Review of Justice and Legal Certainty in Indonesia)." MIMBAR YUSTITIA 2(2), 2018, pp.142-158.

6 Ade Irawan Taufik, "Sinergitas Peran dan Tanggung Jawab Advokat dan Negara dalam Pemberian Bantuan Hukum Cuma-Cuma", Jurnal Rechts Vinding: Media Pembinaan Hukum Nasional, 2(1), 2013, pp. 48-49. See also Muten Nuna, Dince Aisa Kodai, and Roy Marthen Moonti, "Code of Ethics and the Role of Advocates in Providing Legal Aid to the Poor". Indonesian Journal of Advocacy and Legal Services 1(2), 2020, pp. 259-274. 
race, sex, color, nationality, language, religion, as well as different views and other statuses. In Article 34 paragraph (1) of the 1945 Constitution, it is clear that providing legal assistance to citizens who are poor and disadvantaged is due to legal assistance as a right of every citizen. The basis for the consideration that legal aid is the right of every citizen is that the State is obliged to guarantee the constitutional rights of every citizen regarding guarantees, protection, recognition, and legal certainty that are just and equal treatment before the law. ${ }^{7}$ The state recognizes the existence of economic, political, social, cultural and civil rights for the poor. Constitutionally the poor have the right to be represented and defended both inside and outside the court (access to legal counsel). Legal aid as part of the rights of people who can not afford that can be obtained from (pro bono public) as a translation of equality before the law. ${ }^{8}$

The basis for the provision of legal aid by the State is that the State is responsible for providing legal assistance to citizens who are unable as a form of access to justice and equality before the law. The state should provide legal assistance by creating or forming regulations as a legal basis for implementing legal assistance for disadvantaged citizens in Indonesia. Since 2011 the country has passed Law No. 16 of 2011 concerning Legal Aid (Legal Aid Act). This law becomes the legal pay for organizing legal aid in Indonesia. The purpose of establishing legal aid is based on Article 3 of Law Number 16 of 2011 concerning Legal Aid, namely:

1. Guarantee and fulfill the rights of recipients of legal assistance to get access to justice

2. Realizing the constitutional rights of all citizens in accordance with the principle of equality of law

3. Ensuring certainty in the implementation of legal aid to be carried out evenly throughout the territory of the Republic of Indonesia

4. Establish an effective, efficient, effective and accountable court. And article 2 explains that this is carried out based on the principles of justice, openness, equality before the law, efficiency, effectiveness, and accountability. ${ }^{9}$

7 Ahmad Fatah, "Regional Legal Assistance Bantuan Hukum di Daerah", Rechtsidee, 2(1), pp. 1-2. For more comprehensive comparison, please also see Ristina Yudhanti, Saru Arifin, and Fauziah Rismadini. "The Protection to Victims of Violence Based on Gender As a Fulfillment of the Constitutional Rights in the Perspective of Human Rights in Boyolali's District, Indonesia”. JILS (Journal of Indonesian Legal Studies) 2(1), 2017, pp. 15-24; Angga, \& Ridwan Arifin. "Penerapan Bantuan Hukum Bagi Masyarakat Kurang Mampu di Indonesia.” DIVERSI: Jurnal Hukum 4(2), 2019, pp. 218-236.

8 A.P.M. Zen, \& D. Hutagalung, Panduan Bantuan Hukum di Indonesia, Jakarta, LBH Jakarta, pp. 47-48.

9 F. Handayani, Bantuan Hukum di Indonesia, Yogyakarta, Kalimedia, 2016, pp. $97-$ 99. 


\section{Aji \& Ilyasa}

The Law on Legal Aid is different from the free legal aid provided as referred to in Law No.18 of 2003 concerning Advocates. The Legal Aid Law regulates the provision of legal assistance provided by the State to Indonesian citizens, including the poor. Providing free legal assistance by advocates is a form of service that is required by law to advocates for the poor. The State's way of providing legal assistance is by providing funds to legal aid providers (legal aid institutions, community organizations, universities, etc.). Providing legal assistance as a State obligation, the State can also determine the conditions for legal aid providers and recipients, including advocates as legal aid providers based on the Legal Aid Law. Advocates in providing legal assistance as implementing legal aid by the State are regulated by the Legal Aid Act, not an advocate's dedication by providing free legal assistance under what is stipulated in the Advocate Law. The provision of legal assistance is contained in the philosophy of human rights in Indonesia, namely the 1945 Constitution. ${ }^{10}$

Indonesia as a democratic and law-based country, the right to legal assistance is part of human rights. Human rights are basic rights that are universally recognized and are inherent in every human being since he was born. Every human being has this right because of his nature as a human being. Law No.39 of 1999 concerning human rights formulates that human rights as a set of rights inherent in their nature and human existence as creatures of God Almighty and His grace is respected, upheld, and protected by the State, law, the government, and everyone for the sake of honor and protection of human dignity. The right to obtain legal assistance as a fundamental or fundamental right for everyone affected by legal issues. Obtain legal assistance as a form of access to justice for those who are or are dealing with the law. When experiencing legal problems, economically capable people can appoint an advocate or more to assist him in legal matters. Likewise, citizens who can not afford (poor) can ask for the defense of an advocate or more to help him in a legal case. From a humanitarian point of view, it is unfair. If poor citizens cannot afford the services of an advocate because of economic conditions, there is the right to legal assistance for those who cannot so

10 Ajie Ramdan, "Bantuan Hukum Sebagai Kewajiban Negara untuk Memenuhi Hak Konstitusional Fakir Miskin”, Jurnal Konstitusi, 11(2), pp. 233-234. It was further emphasized that the provision of legal aid is a supporting tool for law enforcement in general and efforts to protect human rights from arbitrary actions by law enforcement officials. Law enforcement officers (criminal) are a component of the structure of criminal law, so no matter how perfect the substance of criminal law without law enforcement, there is no benefit in realizing the objectives of the criminal justice system. The substance of legal aid in Indonesia is the most basic question, namely whether legal aid is mandatory or is it only required after certain conditions have been met. Legal aid is an important instrument in the Criminal Justice System because it is part of the protection of human rights, especially to the right to freedom and the rights to the lives of suspects/defendants. 
that he can obtain justice as a manifestation of the constitutional rights of every citizen guaranteed by Country. ${ }^{11}$

\section{VARIOUS REGULATIONS PROVIDING LEGAL AID FOR CITIZENS WHO CAN NOT AFFORD}

Legal aid is defined as any form of assistance or service provision relating to legal issues provided by someone who has the legal expertise to those involved in direct or indirect causes by prioritizing those who are unable. ${ }^{12}$ Legal aid legally in Law Number 16 of 2011 concerning legal aid as a legal service free of charge to legal aid recipients In Indonesia the right to legal aid is not explicitly stated but there are at least three provisions in the 1945 Constitution which become reference to guaranteeing the right to legal assistance as part of human rights. Meanwhile, the poor are the responsibility of the State which has been regulated in Article 34 of the 1945 Constitution which reads, "The poor and displaced children are cared for by the State". Therefore legal assistance is not mercy by the State, but it is the human right of every individual. Legal aid is the responsibility of the State, government, society, the legal profession, and all parties in the community. In the rule of law, the defense of the poor as an incarnation of equality before the law and the right to be defended by an advocate or legal counsel is based on a sense of justice. ${ }^{13}$

Law 16 of 2011 concerning Legal Aid provides protection for citizens' rights in the legal process. There are two basic backgrounds for the enactment of the Legal Aid Law, namely:

1. State guarantees of the constitutional rights of every person to obtain recognition, guarantees, protection, as well as fair legal certainty and equal treatment before the law as a means of protection for human rights

2. The state is responsible for providing legal assistance to the poor as a manifestation of access to justice. The legal aid referred to the legal services provided by legal aid providers, namely legal aid institutions or organizations that provide free legal services to legal aid recipients.

Based on article 3 of the Legal Aid Act, the organization of legal aid aims to:

11 F. Handayani, Op.Cit., pp. 100-101.

Ajie Ramdan, Op.Cit., p. 236.

13 F.H. Winarta, Bantuan Hukum di Indonesian Hal untuk Didampingi Penasehat Hukum Bagi Semua Warga Negara, Jakarta, Elex Media Komputindo, pp. 114-115; F.H. Winarta, Bantuan Hukum: Suatu Hak Asasi Manusia Bukan Belas Kasihan, Jakarta, Elex Media Komputindo, pp. 56-57. 


\section{Aji \& Ilyasa}

1. Ensure the fulfillment of the right of the recipient of legal assistance to gain access to justice

2. Realizing the constitutional rights of all citizens under the principle of equality before the law

3. Ensuring the certainty that the implementation of legal aid is carried out evenly throughout Indonesia

4. Realizing an effective, efficient and accountable court. ${ }^{14}$

In article 3 of Law Number 16 of 2011 concerning Legal Aid, it can be concluded that legal aid is an embodiment of access to justice for all Indonesian citizens without exception as well as an effort to encourage improvements in the justice system in Indonesia. Whereas based on article 4 of Law Number 16 the of 2011, it is determined that:

1. Legal aid is given to legal aid recipients who face legal problems

2. Assistance as referred to in article 1 covers civil, criminal and administrative law matters in litigation and non-litigation

3. Assistance, as referred to in paragraph 1, includes exercising power of attorney, accompanying, representing, defending, and/or taking other legal actions for the legal benefit of the recipient of legal assistance.

In addition to Law Number 16 of 2011 concerning Legal Aid as a guarantee of justice to protect the rights of the poor in Indonesia can be found in:

1. Law Number 48 of 2009 concerning Judicial Power

Legal assistance in this arrangement is contained in Chapter XI in articles 56 and 57. Article 56 paragraph 1 which explains that every person involved in a case has the right to obtain legal assistance, as well as article 56 paragraph 2 that the state bears the cost of the case for justice seekers who are unable. Then further on Article 57 paragraph that in every district court a legal aid post is formed for justice prisoners who are unable to obtain legal assistance as intended by legal assistance provided free of charge at all levels of the court until the decision on the case has been obtained. the legal force that remains under statutory provisions as a legal basis.

2. Law Number 18 of 2003 concerning Advocates

Legal assistance for this regulation can be found in Chapter I in Article 1 paragraph 9 and Chapter VI in Article 22 paragraph 1. In Article 1 paragraph 9 it explains that legal assistance as a legal service is provided by an advocate free of charge to clients who are unable and in article 22 paragraph 1 explains that a legal advocate for giving legal assistance free of charge to justice seekers who are unable.

14 F. Handayani, Op.Cit., pp. 132-133. 


\section{Law Number 49 of 2009 concerning General Judiciary}

To bring about justice based on a sense of justice, legal assistance can be found in Article 68B which explains that everyone who is involved in a case has the right to obtain legal assistance and the state bears the cost of the case for justice seekers who are unable.

4. Law Number 51 of 2009 concerning State Administrative Court Legal assistance in state administrative justice contained in Law Number 51 of 2009 is contained in article 57 which explains that the right to be accompanied and represented by a power of attorney. Then based on Law Number 5 of 1986 article 60 describes the dispute for free on the condition that the evidence is not capable. Then, in article 61 explains the court's obligations related to stipulating petition for free. ${ }^{15}$

5. Law No.50 of 2009 concerning the Second Amendment to Law No.7 of 1989 concerning Religious Courts

Regarding legal assistance in this regulation, contained in article 60B and article 60C. Article 60B explains that every person involved in a case has the right to obtain legal assistance and the state bears the cost of the case for those who cannot afford justice. Whereas article $60 \mathrm{C}$ explains that in every religious court a legal post is formed for justice seekers who are unable to obtain legal assistance, legal assistance is provided free of charge to all courts until the decision on the case receives a permanent legal force.

6. Law No.8 of 1981 concerning the Criminal Procedure Code

Regarding legal assistance in this regulation can be found in Article 54. Article 54 explains that in the interests of the defence of the suspect or the defendant is entitled to obtain legal assistance from one or more legal advisers during the time and at each level of examination.

In addition to Laws and Regulations regarding Legal Aid more specifically it is also contained in the Indonesian Advocates Association (PERADI) Code of Ethics in article 7 point $\mathrm{H}$ that an advocate should be able to provide legal assistance free of charge (prodeo) to people who Not capable. The Government has also issued Government Regulation No. 83 of 2008 concerning Requirements and Procedures for Providing Free Legal Aid as legal services provided by an advocate without receiving honorarium payments including providing legal consultation, exercising power, representing, assisting, defending, and taking action other law for the benefit of justice seekers who are not able to. Regarding legal assistance can also be found in the Instruction of the Minister of Justice of the Republic of Indonesia Number: M.03-um.06.02 of 1999 which explains that those who are less capable are those who have a very small income so that it is not enough to finance the case in court which

15 I.W.P.S. Kalo, E. Putra, \& E. Ikhsan, "Pelaksanaan Pemberian Bantuan Hukum Dikaitkan dengan Undang-Undang No. 16 Tahun 2011 tentang Bantuan Hukum", Arena Hukum, 8(3), 2015, pp. 330-331. 


\section{Aji \& Ilyasa}

this is determined by the Head of District Court based on the statement of the Village Head and Lurah. ${ }^{16}$

The right to legal aid as part of a judicial process that is fair and inherent in the principles of the rule of law and is one of the principles of human rights. The principle of equality of law as one of the universal human rights principles is listed in article 7 of the General Declaration of Human Rights (UDHR) and the International Covenant on Civil and Political Rights (ICCPR). Articles 16 and 26 of the ICCPR guarantee equality before the law. All people have the right to receive legal protection and discrimination is not permitted. The right to legal aid is $a$ non-derogable right, which means that the right is absolute and must not be reduced by the state in an emergency.

The requirements to obtain legal assistance are based on Article 14 paragraph (3) of the ICCPR, which is in the interests of justice and unable to pay an advocate. Both of these conditions must be fulfilled and not part of the alternative requirements. In this case, the ICCPR does not explain what is meant by the interests of justice and also whether legal assistance is only for criminal cases and not civil cases or other cases. The Human Rights Council translates the interests of justice through jurisprudence. Regarding legal assistance, the Human Rights Commission jurisdiction states that:

1. The state must be able to guarantee the right to effective legal assistance and the rights of suspects and defendants to choose lawyers. Advocates appointed by the court must be able to provide effective legal assistance and the defendant must be allowed to be able to choose an advocate who can provide effective legal assistance.

2. The state must be able to guarantee the right of access to legal assistance in every examination. A closed examination system such as a crime against the State allows no access to legal assistance. In these conditions, access to legal assistance must be guaranteed.

3. The right of a suspect or defendant to be able to communicate with an advocate / family, as well as the right to prepare a defense without intervention from the state.

4. The state must be able to guarantee that the suspect / defendant has the right to choose an advocate and not be forced to accept an

16 I.K. Makinara, "Pengaruh Bantuan Hukum Terhadap Masyarakat Miskin (Meninjau Undang-Undang Nomor 16 Tahun 2011 tentang Bantuan Hukum)", Jurnal Rechts Vinding: Media Pembinaan Hukum Nasional,, 2(1), pp. 6-7. See also Adelita Lubis, "Peran Advokat dalam Penegakan Hukum di Organisasi Asosiasi Advokat Indonesia Cabang Medan.” JPPUMA Jurnal Ilmu Pemerintahan dan Sosial Politik Universitas Medan Area 2(2), 2014, pp. 176-192; Ria Juliana, and Ridwan Arifin, "Anak dan Kejahatan (Faktor Penyebab dan Perlindungan Hukum)." Jurnal Selat 6(2), 2019, pp. 225-234; Herning Setyowati, and Nurul Muchiningtias. "Peran Advokat Dalam Memberikan Bantuan Hukum Kepada Masyarakat dalam Perspektif Hak Asasi Manusia”. Lex Scientia Law Review 2(2), 2018, pp. 155 - 168. 
advocate appointed by the court to him. The state must be able to guarantee the competence of advocates who can provide impartial legal assistance.

Those who belong to the group who are unable or poor certainly cannot fight for their right to be helped to obtain sufficient legal assistance. Every person who faces a legal case has the right to be accompanied by an advocate of his own choice to be able to protect his rights and accompany him in his defense. If a person cannot pay for the services of an advocate, qualified advocates must be appointed for him and given adequate time and adequate facilities to be able to communicate with his advocate. ${ }^{17}$

\section{THE PROBLEM OF LEGAL AID IN INDONESIA: BETWEEN OBLIGATIONS OF ADVOCATES AND STATE RESPONSIBILITIES}

Legal aid is defined as an effort to help those who are not capable of the legal field. According to Adnan Buyung Nasution, this effort has three interrelated aspects, the first being concerning the formulation of legal rules. The aspect of the formulation of legal rules, in this case, it will be very potential if it considers that the legal rules that are present are considered to be perfect and strong enough to be able to protect the poor. Related to the presence of existing legal rules, a review needs to be done in the context of improvements and additions to the rule of law to be able to keep up with the speed of the dynamics of social life that develops from time to time. The second aspect is regarding the supervision of the mechanism to maintain the rule of law so that it seems obedient in this aspect can not yet get attention in terms of legal aid activities. This can be motivated by factors in the lack of facilities owned by aid organizations law in terms of funding facilities and experts. In this aspect, the presence of legal aid organizations is very important because it can play a role as one of the elements of society that can oversee the implementation of all of them. The last aspect is about community education specifically to be able to increase public awareness related to the rights and obligations they have. ${ }^{18}$

The Legal Aid Law in Article 5 states that legal assistance is given to people or groups of poor people who cannot fulfill their basic rights properly and independently. Furthermore, it is seen in Article 6 paragraph (3) of Government Regulation No.42 of 2013 containing rules regarding requests for legal assistance submitted by attaching SKTM

17 F. Handayani, Op.Cit., pp. 101-103.

18 Adnan Buyung Nasution, 2000, Op.Cit., p. 7; Adnan Buyung Nasution, 2009, Op.Cit., pp. 66-67. 


\section{Aji \& Ilyasa}

(Not Capable Certificate). There are differences in requirements for requests for legal assistance by Supreme Court regulations and the Legal Aid Act. The Supreme Court provides a requirement by making or attaching a statement or statement that a defendant is an incapable person, whereas in the Legal Aid Act requires to attach SKTM. ${ }^{19}$ The obligation of an advocate in providing legal assistance to underprivileged people or poor groups is strictly emphasized in Article 22 paragraph (1) of the 2003 Advocate Law, which states that an advocate is obliged to provide legal assistance free of charge for justice seekers. who can't afford it? Because of the type of sanctions that are not strong enough and the enforcement of sanctions that are not strict by advocate organizations, then in its development, the provision of the obligation to provide legal assistance for free is still considered to be a casual work that has no meaning and even views legal aid as a form of "professional charity". Frans Hendra Winarta said that giving legal aid to the poor as a form of upholding human rights and not a form of mercy. ${ }^{20}$

The perspective that was considered wrong was the reason why in the process of institutionalizing legal aid, it had stalled and did not bring hope to become a collective movement. In general, the legal aid program run by advocate organizations is still based on the voluntary nature of the administrators of the legal aid program of an advocacy organization and has not yet become a massive movement involving members and fellow advocate organizations. These problems also affect poor people or groups of society. In reality, advocate organizations as providers of legal aid services still have minimal capacity to be able to provide legal aid services to poor people or groups of people. Another problem is funding. Legal aid institutions generally seek their funds to finance their operations so that this affects the sustainability of the legal aid provided. The distribution of advocates in Indonesia is also uneven to all corners and only limited to big cities so that it becomes a problem for the community to seek justice. ${ }^{21}$

Providing free legal assistance in its development has experienced obstacles and setbacks. As described by Satjipto Rahardjo, the development of legal aid is approaching a "legal industry". This means that professionals (advocates) prefer to run a business rather than legal aid for the poor. Legal aid has developed as a large corporation involving practice in the form of large units and legal services are seen as a commodity that can be sold like a business. ${ }^{22}$ These developments in terms of providing free legal assistance are not only the responsibility of an advocate, but the state must constitutionally be able to guarantee the constitutional rights of everyone to be able to get protection, guarantee,

19 I.W.P.S. Kalo, E. Putra, \& E. Ikhsan, Op.Cit., p. 337.

20 Winarta, 2000, Loc.Cit; Winarta, 2010, Loc.Cit.

21 Ade Irawan Taufik, Op.Cit., p. 50.

22 Satjipto Rahardjo, Penegakan Hukum Progresif, Jakarta, Penerbit Buku Kompas, p. 81. 
and legal certainty that is fair and equal treatment before the law as a means of protecting human rights. The state is responsible for providing legal assistance to the poor as a manifestation of access to justice.

The effort of the State in overcoming the problems experienced by advocates is to provide free legal assistance that has been accommodated in the Government Regulation Number 83 of 2008 concerning Requirements and Procedures for Providing Free Legal Aid and the Supreme Court Circular Letter Number 10 of 2010 concerning Legal Aid Guidelines as amended by Supreme Court Regulation No. 1 of 2014 concerning Guidelines for Providing Legal Services to the Poor in Courts. ${ }^{23}$ However, the efforts of the State in this matter are constrained because they can only accommodate individual and conventional legal assistance, not as a manifestation of the welfare model for all Indonesian citizens.

The advocate movement which is still individual and not as a collective movement results in the low quality of legal aid produced. The enactment of the Legal Aid Act in 2011 does not mean that the obligation of an advocate in providing legal assistance is eliminated, but in the explanation of Article 6 paragraph (2), it is emphasized that the provision of legal aid, in this case, does not reduce the obligation of the advocate profession to be able to provide legal assistance based on in the Advocate Law of 2003. So that the role of advocates in the provision of legal assistance in a manner that is regulated in the Advocate Law can be in synergy with the role of the State in accordance with those stipulated in the 2011 Legal Aid Act. With the enactment of the Law, Legal aid is the role of the State to realize the welfare legal assistance model will be relatively easy to achieve. Philosophically, the Legal Aid Law according to Wicipto Setiadi, can be interpreted in the context of expanding people's access to justice and this makes it easier for the poor to be able to access justice. $^{24}$

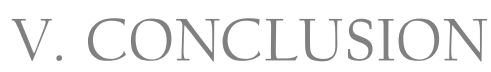

The assistance referred to in Act Number 16 of 2011 concerning Legal Aid as legal services are free of charge to legal aid recipients. Indonesia as a legal state defends the poor as an embodiment of equality before the

23 Government Regulation Number 83 of 2008 concerning Requirements and Procedures for Providing Free Legal Aid, retrieved from http://ditjenpp.kemenkumham.go.id/arsip/ln/2008/pp83-2008.pdf; the Supreme Court Circular Letter Number 10 of 2010 concerning Legal Aid Guidelines, retrieved from http://www.pta-jambi.go.id/attachments/article/1027/SEMANo_10-2010-Pedoman-Bantuan-Hukum.pdf as amended by Supreme Court Regulation No. 1 of 2014 concerning Guidelines for Providing Legal Services to the Poor in Courts, retrieved from https://bawas.mahkamahagung.go.id/bawas_doc/doc/perma_nomor_01_tahun_201 4.pdf

24 Ade Irawan Taufik, Op.Cit., pp. 60-61. 


\section{Aji \& Ilyasa}

law based on a sense of justice that has the aim to guarantee the right for legal aid recipients to access justice, the realization of the constitutional rights of all citizens in accordance with the principle of equality before the law, ensuring certainty the implementation of aid to be evenly distributed throughout the territory of Indonesia as well as the realization of an effective, efficient and accountable justice for all Indonesian citizens without exception as an effort to encourage improvements in the justice system in Indonesia. The right to legal aid as part of a fair trial process in the rule of law state and is one of the universal human rights principles. As a state of law that upholds the presence of human rights, the state recognizes and protects the rights of every individual without discriminating against the background for the realization of equal treatment before the law.

The thing that becomes the basis in providing legal assistance by the state is that the state is responsible for providing legal assistance to disadvantaged citizens as a form of access to justice and equality before the law. The state has an obligation to be able to provide legal assistance by creating or forming regulations as a legal basis for implementing legal assistance for disadvantaged citizens in Indonesia. In the formation of regulations, the Legal Aid Act differs from the provision of free legal assistance. The Law on Legal Aid regulates the provision of legal assistance provided by the state to Indonesian citizens, including the poor. Whereas giving legal aid for free by advocates is a form of service that is required by law. The way the state provides legal assistance is by providing funds to legal aid providers. In reality, in terms of providing legal aid in its development, there are problems other than funding, such as insufficient sanctions and less strict enforcement by advocate organizations related to advocates in providing free legal assistance and are considered as a form of professional charity. In addition to that, the legal aid program that is implemented is still based on the voluntary nature of the legal aid management and has not become a massive movement and an uneven distribution of advocates in all regions of Indonesia. Although the state has tried to solve this problem by issuing legal regulations. In reality, there is still a need for synergy between legal aid providers and the state to realize access to justice and equality before the law for disadvantaged citizens.

\section{REFERENCES}

Abdurrahman, A. (1980). Pembaharuan Hukum Acara Pidana dan Hukum Acara Pidana Baru di Indonesia. Bandung: Alumni.

Angga, A., \& Arifin, R. (2019). Penerapan Bantuan Hukum Bagi Masyarakat Kurang Mampu di Indonesia. DIVERSI: Jurnal Hukum, 4(2), 218-236. 
Arifin, R., Rasdi, R., \& Alkadri, R. (2018). Tinjauan Atas Permasalahan Penegakan Hukum dan Pemenuhan Hak dalam Konteks Universalime dan Relativisme Hak Asasi Manusia di Indonesia. Legality: Jurnal Ilmiah Hukum, 26(1), 17-39.

Arifin, R. (2020). Legal Services and Advocacy in the Industrial Revolution 4.0: Challenges and Problems in Indonesia. Indonesian Journal of Advocacy and Legal Services, 1(2), 159-162. https://doi.org/10.15294/ijals.v1i2.36488.

Asfinawati, Santosa, M.A. (2007). Bantuan Hukum Akses Masyarakat Marjinal Terhadap Keadilan Tinjauan Sejarah, Konsep, Kebijakan, Penerapan, dan Perbandingan di Berbagai Negara. Jakarta: LBH Jakarta.

Fatah, A. (2015). Regional Legal Assistance Bantuan Hukum di Daerah, Rechtsidee, 2(1), 1-10. http://doi.org/10.21070/jihr.v2i1.7

Gultom, M. (2008). Perlindungan Hukum Terhadap Anak Dalam Sistem Peradilan Pidana Anak di Indonesia. Bandung: PT Refika Aditama.

Handayani, F. (2016). Bantuan Hukum di Indonesia. Yogyakarta: Kalimedia.

Harahap, Y. (2009). Pembahasan Permasalahan dan Penerapan KUHAP Penyidikan dan Penuntutan. Jakarta: Sinar Grafika.

Juliana, R., \& Arifin, R. (2019). Anak dan Kejahatan (Faktor Penyebab dan Perlindungan Hukum). Jurnal Selat, 6(2), 225-234.

Kalo, I.W.P.S., Putra, E., Ikhsan, E. (2015). Pelaksanaan Pemberi Bantuan Hukum Dikatikan Dengan Undang-Undang No.16 Tahun 2011 Tentang Bantuan Hukum, Arena Hukum, 8(3), 318-341. http://dx.doi.org/10.21776/ub.arenahukum.2015.00803.2

Kasim, N. M., \& Kamba, S. N. M. (2019). Implementation of Assistance for Victims of Domestic Violence. Indonesian Journal of Advocacy and Legal Services, 1(1), 139-152.

Lubis, A. (2014). Peran Advokat dalam Penegakan Hukum di Organisasi Asosiasi Advokat Indonesia Cabang Medan. JPPUMA Jurnal Ilmu Pemerintahan dan Sosial Politik Universitas Medan Area,2(2), 176-192.

Makinara, I.K. (2013). Pengaruh Bantuan Hukum Terhadap Masyarakat Miskin (Meninjau Undang-Undang Nomor 16 Tahun 2011 tentang Bantuan Hukum), Jurnal Rechts Vinding: Media Pembinaan Hukum Nasional, 2(1), 1-15. Retrieved from https://rechtsvinding.bphn.go.id/ejournal/index.php/jrv/articl e/view/78

Nasution, A.B. (2000). Bantuan Hukum di Indonesia. Jakarta: LP3ES.

Nasution, A.B. (2009). Bantuan Hukum dan Hak Asasi Manusia. Bandung: Mandar Maju

Naziah, F. (2017). Analisis Perlindungan Hukum Terhadap Wanita Korban Pemerkosaan. Lex Scientia Law Review, 1(1), 105-112. https://doi.org/10.15294/lesrev.v1i01.19487. 
Aji \& Ilyasa

Nuna, M., Kodai, D. A., \& Moonti, R. M. (2020). Code of Ethics and the Role of Advocates in Providing Legal Aid to the Poor. Indonesian Journal of Advocacy and Legal Services, 1(2), 259-274. https://doi.org/10.15294/ijals.v1i2.35986.

Putri, K. D. A., \& Arifin, R. (2018). Tinjauan Teoritis Keadilan dan Kepastian dalam Hukum di Indonesia (The Theoretical Review of Justice and Legal Certainty in Indonesia). MIMBAR YUSTITIA, 2(2), 142-158.

Rahardjo, S. (2010). Penegakan Hukum Progresif. Jakarta: Penerbit Buku Kompas

Ramdan, A. (2014). Bantuan Hukum Sebagai Kewajiban Negara Untuk Memenuhi Hak Konstitusional Fakir Miskin, Jurnal Konstitusi, 11(2), 233-255. https://doi.org/10.31078/jk\%25x.

Rukmini, M. (2007). Perlindungan Hak Melalui Asas Praduga Tidak Bersalah dan Asas Persamaan Kedudukan Dalam Hukum dalam Sistem Peradilan di Indonesia. Bandung: Alumni

Republic of Indonesia. (1981). Law Number 8 of 1981 concerning the Criminal Procedure Code (State Gazette of the Republic of Indonesia of 1981 Number 76, Supplement to the State Gazette of the Republic of Indonesia Number 3209) [Undang-Undang Nomor 8 Tahun 1981 tentang Kitab Undang-Undang Hukum Acara Pidana (Lembaran Negara Republik Indonesia Tahun 1981 Nomor 76, Tambahan Lembaran Negara Republik Indonesia Nomor 3209)]

Republic of Indonesia. (1999). Law Number 39 of 1999 concerning Human Rights (State Gazette of the Republic of Indonesia of 1999 Number 165, Supplement to the State Gazette of the Republic of Indonesia Number 3886) [Undang-Undang Nomor 39 Tahun 1999 tentang Hak Asasi Manusia (Lembaran Negara Republik Indonesia Tahun 1999 Nomor 165, Tambahan Lembaran Negara Republik Indonesia Nomor 3886)]

Republic of Indonesia. (2003). Law Number 18 of 2003 concerning Advocates (State Gazette of the Republic of Indonesia of 2003 Number 49, Supplement to the State Gazette of the Republic of Indonesia Number 4288) [Undang-Undang Nomor 18 Tahun 2003 tentang Advokat (Lembaran Negara Republik Indonesia Tahun 2003 Nomor 49, Tambahan Lembaran Negara Republik Indonesia Nomor 4288)]

Republic of Indonesia. (2009). Law Number 48 of 2009 concerning Judicial Power (Statute Book of the Republic of Indonesia Number 157 of 2009, Supplement to Statute Book of the Republic of Indonesia Number 5076) [Undang-Undang Nomor 48 Tahun 2009 tentang Kekuasaan Kehakiman (Lembaran Negara Republik Indonesia Tahun 2009 Nomor 157, Tambahan Lembaran Negara Republik Indonesia Nomor 5076)]

Republic of Indonesia. (2009). Law Number 49 of 2009 concerning Second Amendment to Law Number 2 of 1986 concerning General 
Judiciary (State Gazette of the Republic of Indonesia Number 158 of 2009, Supplement to the State Gazette of the Republic of Indonesia Number 5077) [Undang-Undang Nomor 49 Tahun 2009 tentang Perubahan Kedua Atas Undang-Undang Nomor 2 Tahun 1986 tentang Peradilan Umum (Lembaran Negara Republik Indonesia Tahun 2009 Nomor 158, Tambahan Lembaran Negara Republik Indonesia Nomor 5077)]

Republic of Indonesia. (2009). Law Number 50 of 2009 concerning Second Amendment to Law Number 7 of 1989 concerning Religious Courts (State Gazette of the Republic of Indonesia Number 159 of 2009, Supplement to the State Gazette of the Republic of Indonesia Number 5078) [Undang-Undang Nomor 50 Tahun 2009 tentang Perubahan Kedua Atas Undang-Undang Nomor 7 Tahun 1989 tentang Peradilan Agama (Lembaran Negara Republik Indonesia Tahun 2009 Nomor 159, Tambahan Lembaran Negara Republik Indonesia Nomor 5078)]

Republic of Indonesia. (2009). Law Number 51 of 2009 concerning the Second Amendment to Law Number 5 of 1986 concerning State Administrative Court (State Gazette of the Republic of Indonesia of 2009 Number 160, Supplement to the State Gazette of the Republic of Indonesia Number 5079) [Undang-Undang Nomor 51 Tahun 2009 Tentang Perubahan Kedua Atas Undang-Undang Nomor 5 Tahun 1986 Tentang Peradilan Tata Usaha Negara (Lembaran Negara Republik Indonesia Tahun 2009 Nomor 160, Tambahan Lembaran Negara Republik Indonesia Nomor 5079)]

Republic of Indonesia. (2011). Law Number 16 of 2011 concerning Legal Aid (State Gazette of the Republic of Indonesia of 2011 Number 104, Supplement to the State Gazette of the Republic of Indonesia Number 5248) [Undang-Undang Nomor 16 Tahun 2011 tentang Bantuan Hukum (Lembaran Negara Republik Indonesia Tahun 2011 Nomor 104, Tambahan Lembaran Negara Republik Indonesia Nomor 5248)]

Republic of Indonesia. (2008). Government Regulation Number 83 Year 2008 Concerning Requirements and Procedure for Providing Legal Aid and Procedure for Providing Free Legal Aid [Peraturan Pemerintah Nomor 83 Tahun 2008 Tentang Persyaratan dan Tata Cara Pemberian Bantuan Hukum dan Tata Cara Pemberian Bantuan Hukum Secara Cuma-Cuma]

Republic of Indonesia. (2008). Government Regulation Number 83 of 2008 concerning Requirements and Procedures for Providing Free Legal Aid, retrieved from http://ditjenpp.kemenkumham.go.id/arsip/ln/2008/pp83-2008.pdf

Republic of Indonesia. (2010). the Supreme Court Circular Letter Number 10 of 2010 concerning Legal Aid Guidelines, retrieved from http://www.pta-jambi.go.id/attachments/article/1027/SEMANo_10-2010-Pedoman-Bantuan-Hukum.pdf 


\section{Aji \& Ilyasa}

Republic of Indonesia. (2014). Supreme Court Regulation No. 1 of 2014 concerning Guidelines for Providing Legal Services to the Poor in Courts, retrieved from https://bawas.mahkamahagung.go.id/bawas_doc/doc/perma_nom or_01_tahun_2014.pdf

Setyaningrum, A., \& Arifin, R. (2019). Analisis Upaya Perlindungan dan Pemulihan Terhadap Korban Kekerasan dalam Rumah Tangga (KDRT) Khususnya Anak-Anak dan Perempuan. Jurnal Ilmiah Muqoddimah: Jurnal Ilmu Sosial, Politik dan Hummaniora, 3(1), 9-19.

Setyowati, H., \& Muchiningtias, N. (2018). Peran Advokat Dalam Memberikan Bantuan Hukum Kepada Masyarakat Dalam Perspektif Hak Asasi Manusia. Lex Scientia Law Review, 2(2), 155 - 168. https://doi.org/10.15294/lesrev.v2i2.27582.

Taufik, A.I. (2013). Sinergitas Peran dan Tanggung Jawab Advokat dan Negara dalam Pemberian Bantuan Hukum Cuma-Cuma. Jurnal Rechts Vinding: Media Pembinaan Hukum Nasional, 2(1), 47-63. Retrieved from https://rechtsvinding.bphn.go.id/ejournal/index.php/jrv/articl e/view/81

Winarta, F.H. (2000). Bantuan Hukum: Suatu Hak Asasi Manusia Bukan Belas Kasihan. Jakarta: Elex Media Komputindo.

Winarta, F.H. (2010). Bantuan Hukum di Indonesia Hak untuk Didampingi Penasihat Hukum Bagi Semua Warga Negara. Jakarta: Elex Media Komputindo.

Yudhanti, R., Arifin, S., \& Rismadini, F. (2017). The Protection to Victims of Violence Based on Gender as a Fulfillment of the Constitutional Rights in the Perspective of Human Rights in Boyolali's District, Indonesia. JILS (Journal of In.donesian Legal Studies), 2(1), 15-24. https://doi.org/10.15294/jils.v2i01.16638

Zen, A.P.M., Hutagalung, D. (2006). Panduan Bantuan Hukum di Indonesia. Jakarta: LBH Jakarta. 